\title{
HIRARKI
}

Jurnal Ilmiah Manajemen dan Bisnis

http://journal.upp.ac.id/index.php/Hirarki

\section{Pengaruh Word Of Mouth Dan Citra Merek Terhadap Keputusan Berkunjung Pada Wisata Religi Masjid Agung Islamic Centre Kabupaten Rokan Hulu}

\author{
Linda Sari ${ }^{1}$
}

Manajemen, Universitas Pasir Pengaraian, Rokan Hulu, Riau

\section{Info Artikel}

Sejarah Artikel:

Diterima 14 Januari

2019

Disetujui 21 Maret 2019

Dipublikasikan 15 Juni

2019

Keywords:

Islamic Center, Rokan

Hulu, Satisfaction

\begin{abstract}
Abstrak
Penelitian ini bertujuan untuk mengetahui pengaruh word of mouth dan citra merek secara simultan terhadap keputusan berkunjung pada wisata religi Masjid Agung Islamic Centre Kabupaten Rokan Hulu. Teknik analisis data yang digunakan adalah analisis deskriptif dan analisis statistik dengan menggunakan analisis regresi liner berganda. Hasil penelitian dari regresi linear berganda diperoleh persamaan regresi $\mathrm{Y}=5,140+0,059 \mathrm{X} 1+0,830 \mathrm{X} 2$. Pada koefisien determinasi diperoleh nilai $\mathrm{R}$ sebesar 0.679 dan bernilai positif ini menunjukkan bahwa word of mouth dan citra merek berpengaruh signifikan terhadap keputusan berkunjung pada wisatareligi Masjid Agung Islamic Centre Kabupaten Rokan Hulu maka hipotesis peneliti diterima. Dapat disimpulkan bahwa word of mouth dan citra merek pada wisata religi Masjid Agung Islamic Centre Kabupaten Rokan Hulu termasuk dalam kategori cukup baik dengan perolehan nilai TCR sebesar 77,4\% untuk variabel word of mouth, untuk variabel citra merek nilai TCR sebesar $69,05 \%$ dan nilai TCR sebesar $66,16 \%$ untuk variabel keputusan berkunjung.
\end{abstract}

\section{THE EFFECT OF WORD OF MOUTH AND BRAND IMAGE ON DECISION TO VISIT THE GREAT MOSQUE RELIGIOUS TOURISM ISLAMIC CENTER OF ROKAN HULU REGENCY}

\begin{abstract}
This study aims to determine the effect of simultaneous word of mouth and brand image on the decision to visit religious tourism at the Great Mosque of Islamic Center in Rokan Hulu Regency. The data analysis technique used is descriptive analysis and statistical analysis using multiple linear regression analysis. The results of the study of multiple linear regression obtained the regression equation $Y=5.140+0.059 X 1+0.830 \times 2$. In the coefficient of determination, the $R$ value of 0.679 is obtained and this positive value indicates that word of mouth and brand image have a significant effect on the decision to visit the Grand Mosque of the Islamic Center of the Rokan Hulu Regency, the researcher's hypothesis is accepted. It can be concluded that word of mouth and brand image on the religious tour of the Great Mosque of the Islamic Center of Rokan Hulu Regency are included in the fairly good category with the acquisition of a TCR value of $77.4 \%$ for the word of mouth variable, for the brand image variable TCR value of $69.05 \%$ and TCR value of $66.16 \%$ for visiting decision variables.




\section{PENDAHULUAN}

Pariwisata merupakan salah satu sektor yang memegang peranan penting dalam perekonomian Indonesia yaitu sebagai penghasil devisa negara. Indonesia mempunyai perkembangan perdagangan jasa pariwisata yang berfluktuasi, hal tersebut menyebabkan Indonesia berada pada niai ohyang rendah dibandingkan dengan beberapa negara lainnya di dunia.

Pariwisata di Provinsi Riau adalah salah satu sektor ekonomi jasa memiliki prospek yang cerah, namun saat ini belum menunjukkan peranan yang sesuai dengan harapan dalam prospek pembangunan di Indonesia. Pada era globalisasi, pariwisata dijadikan tujuan utama dalam meningkatkan pembangunan suatu daerah.

Saat ini salah satu kota tujuan pariwisata di Riau adalah Kabupaten Rokan Hulu. Hal ini terlihat dengan berdiri megahnya wisata religi Masjid Agung Islamic Centre Kabupaten Rokan Hulu.Masjid Agung Isamic Centre Kabupaten Rokan Hulu mulai dibangun pada tanggal 29 Desember 2008 dan diresmikan penggunaannya pada tanggal 6 Agustus 2010 oleh Bupati Rokan Hulu. Masjid Agung Islamic Center Kabupaten Rokan Hulu dibangun diatas lahan seluas 22 hektar dengan luas bangunan 15.800 $\mathrm{m}^{2}$. Masjid Agung Islamic Centre Kabupaten Rokan Hulu dilengkapi dengan berbagai sarana dan prasarana mulai dari tempat ibadah, penyejuk ruangan, sound system, multimedia, sajadah dari turki sehingga menambah kenyamanan dalam beribadah Masjid Agung Islamic Centre Kabupaten Rokan
Hulu juga dilengkapi dengan sarana MCK yang memadai, tempat wudhu yang nyaman dan bersih. Sarana perpustakaan, baik digital maupun manual yang dilengkapi dengan akses internet, TV Islamic Centre, Radio Islamic Centre, Poliklinik, aula serbaguna dan toserba. Dengan adanya informasi tentang Islamic Center Kabupaten Rokan Hulu dan juga merupakan Masjid Paripurna di tingkat Nasional pada Tahun 2015 dan arsitektur bangunan masjid bergaya modern Arabia. Objek wisata yang menjual keindahan bangunan yang ditunjukkan oleh Masjid Agung Islamic Center kian diminati wisatawan dalam daerah maupun luar daerah untuk menghabiskan waktu libur, pada musim liburan, melalui profil Masjid Agung Islamic Center dan juga informasi dari mulut ke mulut.

Para pengujung Masjid Agung Islamic Centre Kabupaten Rokan Hulu memiliki pengaruh dan respon kepada masyarakat lain yang ingin berkunjung sehingga dapat menentukan keputusan mereka. Menyadari hal tersebut usaha pemahaman akan perilaku komsumen untuk mencapai keberhasilan pemasar sangat penting. Dengan memahami apa yang sebenarnya menjadi keinginan dan kebutuhan konsumen.

Adapun salah satu fenomena yang mendorong keputusan berkunjung ke tempat wisata yaitu adanya pengaruh orang disekitar yang menginformasikan dari mulut kemulut (Word Of Mouth). Hal ini diketahui dari hasil survey semantara dari para pengunjung, yang mengaku bahwa informasi wisata tersebut 
diperoleh dari mulut ke mulut yang dilakukan wisatawan yang sudah pernah pergi kesana, mengundang keingin tahuan wisatawan yang belum pernah berkunjung sehingga mendorong mereka untuk berkunjung ke Masjid Agung Islamic Centre Kabupaten Rokan Hulu. Kebiasaan sebagian besar masyarakat adalah bertukar informasi mengenai hal yang sudah mereka alami.

Selanjutnya, adanya citra merek dari masjid tersebut tentang wisata religi yang terletak pada negeri seribu suluk ini, merupakan representasi dari keseluruhan persepsi terhadap merek yang dibentuk dari informasi dan pengalaman masa lalu terhadap merek tersebut. Citra terhadap merek berhubungan dengan sikap dan tindakan seseorang terhadap suatu objek sangat dtentukankan oleh citra objek tersebut. Konsumen yang memiliki citra yang positif terhadap suatu merek, akan lebih memungkinkan untuk melakukan pembelian. Citra merek inilah yang membedakan Masjid Agung Islamic Centre Kabupaten Rokan Hulu dengan masjid yang lainnya. Hal ini lah yang kemungkinan besar mengakibatkan adanya keputusan mereka untuk berkunjung ke Masjid Agung Islamic Centre Kabupaten Rokan Hulu.

Keputusan berkunjung ke Masjid Agung Islamic Centre Kabupaten Rokan Hulu tidak mudah, ada banyak sekali faktor yang mempengaruhi hal itu. Baik dari faktor internal yaitu dari dalam diri konsumen ataupun pengaruh eksternal yaitu rangsangan luar yang dilakukan, dimana dalam hal ini Pemerintah Kabupaten Rokan Hulu telah berusaha melakukan promosi untuk mempengaruhi dari perilaku masyarakat (konsumen) baik untuk Provinsi Riau dan luardari Provinsi Riau.

Tabel 1.1

Jumlah Wisatawan Yang Berkunjung Pada Wisata Religi Masjid AgungIslamic Centre Kabupaten Rokan Hulu, Tahun 2012 - 2016

\begin{tabular}{|c|c|c|c|}
\hline No & Tahun & Jumlah (Orang) & Peningkatan \\
\hline 1 & 2012 & 79.930 & - \\
\hline 2 & 2013 & 86.921 & $8.75 \%$ \\
\hline 3 & 2014 & 80.231 & $-7.70 \%$ \\
\hline 4 & 2015 & 82.939 & $3.38 \%$ \\
\hline 5 & 2016 & 82.647 & $-0.35 \%$ \\
\hline
\end{tabular}

Sumber : Bagian Informasi, Dokumentasi, Perpustakaan dan Pemandu Tamu Masjid Agung Islamic Centre Kabupaten Rokan Hulu. 
Dapat pula disimpulkan beberapa Rumusan masalah dalam penelitian ini yaitu :

1. Bagaimana word of mouth pengujung yang terjadi pada wisata religi Masjid Agung Islamic Centre Kabupaten Rokan Hulu?

2. Bagaimana citra merek pada wisata religi Masjid Agung Islamic Centre Kabupaten Rokan Hulu?

3. Bagaimana keputusan berkunjung pada wisata religi Masjid Agung Islamic Centre Kabupaten Rokan Hulu?

4. Bagaimana pengaruh word of mouth dan citra merek terhadap keputusan berkunjung pada wisata religi Masjid Agung Islamic Centre Kabupaten Rokan Hulu?

Tujuan- tujuan yang ingin dicapai dalam penelitian ini adalah :

1. Untuk mengetahui word of mouth pengunjung yang terjadi pada wisata religi Masjid Agung 1. Islamic Centre Kabupaten Rokan Hulu

2. Untuk mengetahui citra merek pada wisata religi Masjid Agung Islamic Centre Kabupaten Rokan Hulu

3. Untuk mengetahui keputusan berkunjung pada wisata religi Masjid Agung Islamic Centre Kabupaten Rokan Hulu

4. Untuk mengetahui pengaruh word of mouth dan citra merek terhadap keputusan berkunjung pada wisata 2 . religi Masjid Agung Islamic Centre Kabupaten Rokan Hulu.

\section{Landasan Teori}
a. Word Of Mouth
Word Of Mouth merupakan

usaha meneruskan informasi dari satu konsumen ke konsumen lain dilakukan oleh konsumen dengan sukarela atau tanpa mendapatkan imbalan melalui informasi dari mulut ke mulut (Praswati, 2009: 42). Berdasarkan teori mengenai word of mouth, maka bisa disimpulkan bahwa word of mouth merupakan media promosi yang dilakukan dengan perantara orang untuk menyampaikan pesan mengenai suatu nilai produk atau jasa yang telah digunakan kepada orang lain dan berdampak pada penilaian terhadap produk atau jasa tersebut.

Penelitian Jilian C. Sweeney, Geoffrey N. Soutar and Tim Mazzarol (2012) dengan judul word of mouth measuring the power of individual messages. Selanjutnya penelitian tersebut diadaptasi oleh Andari dan Napu, (2016 :1013) terdapat 3 dimensi WOM yang didasari oleh pemberi (sender) dan penerima (receiver) pesan, yaitu :

Cognitive content, adalah menggambarkan isi dari pesan yang sesuai dengan kinerja, nilai-harga, tanggapan terhadap masalah dan persepsi, sehingga mendukung gagasan bahwa WOM juga memiliki dimensi rasional. Richness of content adalah kekayaan, yang meliputi aspek konten, seperti informasi yang terlibat didalam pesan, bahasa yang digunakan dalam pesan serta intensitas dan kejelasan dari pesan itu sendiri.

Strength of delivery adalah kekuatan dari pengiriman pesan yang disampaikan. Ini berkaitan dengan cara dimana pesan tersebut disampaikan bukan dengan konten. Hal ini mencerminkan kekuatan niat rekomendasi. 


\section{b. Citra Merek}

Citra merek $\left(\mathrm{X}_{2}\right)$ merupakan seperangkat keyakinan, ide dan kesan yang dimiliki oleh seseorang terhadap suatu produk (Kotler 2010:32).

Amanah, (2011:229) menyatakan citra merek dideskripsikan tentang asosiasi yang muncul dibenak konsumen dan keyakinan konsumen terhadap suatu merek untuk menggunakan secara terus-menerus. Indikator citra merek:

1. Kesan professional

Kesan profesional yaitu kesan hasil dari pekerjaan yang dilaksanakan itu bila ditinjau dari segala sisi sudah sesuai dengan porsi, objektif dan dilaksanakan tepat waktu.

2. Kesan modern

yaitu kesan yang dihasilkan bedasarkan saat ini ataupun yang telah diperbaharui.

3. Melayani semua segmen

berarti melayani semua kalangan tanpa terkecuali atau tanpa memilih-milihserta mengklasifikasikannya.

4. Perhatian kepada konsumen yaitu seperti melihat serta memahami keinginan dan kebutuhan konsumen.

\section{c. Keputusan Berkunjung}

Keputusan Berkunjung (Y) proses prilaku pasca pembelian terjadi dengan membandingkan apakah produk yang dibelinya sesuai dengan produk yang dibeli sebelumnya atau tidak (Kotler, 2010 :225).

Tindakan seorang konsumen dalam usahanya untuk mendapatkan atau membeli sebuah barang atau jasa tidak terlepas dari berbagai pertimbangan. Pertimbanganyang berkaitan dengan suatu proses dipengaruhi oleh berbagai faktor yang akhirnya dapat diambil suatu keputusan. Proses prilaku setelah pembelian terjadi dengan membandingkan apakah produk yang dibelinya sesuai dengan produk yang dibeli sebelumnya atau tidak. Keputusan konsumen dalam berbelanja yang berhubungan langsung (Kotler, 2010 : 225).

1. Keragaman produk (product assortment), ini artinya keputusan konsumen mengenai keanekaragaman produk dari segala jenis yang ditawarkan untuk memuaskan kebutuhan dan keinginan konsumen.

2. Layanan dan atmosfer toko, ini artinya keputusan konsumen mengenai layanan dan situasi atau suasana yang dirasakan konsumen untuk memuaskan keinginan atau kebutuhannya.

3. Keputusan harga, yang artinya sejumlah uang (ditambah beberapa barang kalau mungkin) yang dibutuhkan untuk mendapatkan sejumlah kombinasi dari barang beserta pelayanannya.

4. Keputusan promosi, ini artinya arus informasi yang dibuat oleh lembaga atau perusahaan untuk mengarahkan konsumen dalam memutuskan pembelian.

5. Keputusan tempat, artinya lembaga lokasi saluran melaksanakan kegiatan barang atau jasa yang mudah terjangkau oleh konsumen dan memiliki lokasi yang strategis . 
Gambar 2.1.

Kerangka Konseptual

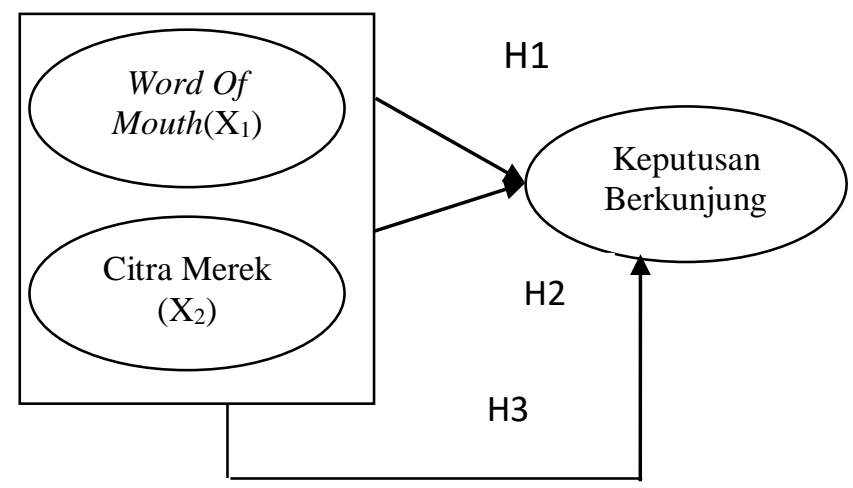

Sumber: Andari dan Napu, $(2016,1013)$

\section{Hipotesis}

Berdasarkan dari kerangka konseptual maka hipotesis penelitian adalah sebagai berikut :

H1: Word of mouth berpengaruh terhadap keputusan berkunjung pada wisata religi Masjid Agung Islamic Centre Kabupaten Rokan Hulu.

H2: Citra merek berpengaruh terhadap keputusan berkunjung pada wisata religi Masjid Agung Islamic Centre Kabupaten Rokan Hulu.

H3: Secara simultan word of mouthdan citra merek berpengaruh terhadap keputusan berkunjung pada wisata religi Masjid Agung Islamic Centre Kabupaten Rokan Hulu.

\section{Populasi}

Populasi adalah wilayah generalisasi yang terdiri atas objek atau subjek yang mempunyai kualitas dan karakteristik tertentu yang ditetapkan peneliti untuk dapat dipelajari dan kemudian ditarik kesimpulannya (Sugiyono, 2010:
73). Dalam penelitian ini yang menjadi populasi adalah konsumen yang berkunjung pada wisata religi Masjid Agung Islamic Centre Kabupaten Rokan Hulu, adapun jumlah populasi pada tahun 2016 sebanyak 82.647 orang.

\section{Sampel}

Sampel adalah sebagian dari jumlah dan karakteristik yang dimiliki oleh populasi tersebut, apa yang dipelajari dari sampel itu maka kesimpulan akan diberlakukan untuk populasi. Untuk itu sampel yang diambil dari populasi harus benarbenar representatif (mewakili). Untuk menentukan besarnya menggunakan rumus Slovin (Sugiyono, 2010: 73).

Metode dalam pengambilan sampel menggunakan accidental sampling yaitu metode dimana dalam menentukan pemilihan sampel telah memenuhi kriteria yang ditentukan oleh peneliti (Sugiyono, 2010:95).

\section{Jenis Dan Sumber Data}

Data Primer

Data primer dalam penelitian ini adalah hasil survey/observasi, 
wawancara terhadap pengunjung wisata religi.

\section{Data Sekunder}

Data sekunder dalam penelitian ini adalah profil Masjid Agung, dokumentasi dan dokumen-dokumen pendukung lainnya yang mendukung terlaksananya penelitian.

\section{TeknikPengumpulan Data}

1. Observasi

2. Kuisioner

\section{Instrumen Penelitian}

Untuk mengukur nilai variabel, penulis menggunakan prosedur pengujian, yaitu :

Untuk mengukur sah atau validnya suatu kuisioner digunakan uji validitas.

Untuk mengukur suatu kuisioner yang mempunyai indikator dari variabel atau konstruk digunakan uji reliabilitas.

\section{UjiPersyaratan Data}

Adapun uji persyaratan data menggunakan pengujian asumsi klasik yang perlu dilakukan dalampenelitian ini, antara lain (Ghozali, 2012: 78) :

\section{Uji Normalitas Data}

Uji normalitas digunakan untuk menguji tingkat kenormalan distribusi variable pengganggu atau residual dalam model regresi

\section{Uji Heteroskedastisitas.}

Heteroskedastisitas adalah kondisi di mana sebaran varian factor atau disturbance tidak konstan sepanjang daerah observasi

\section{Uji Multikolinieritas}

Uji multikolinieritas bertujuan untuk menguji apakah model regresi ditemukan adanya korelasi antar variabel bebas (independent).

Uji multikolinieritas bertujuan untuk menguji apakah model regresi ditemukan adanya korelasi antar variabel bebas (independent).

\section{Uji Regresi Linear Berganda}

Analisis regresi berganda adalah alat uji statistik yang digunakan untuk melakukan estimas imengenai bagaimana perubahan nilai variabel terikat jika nilai variabel bebas dinaikkan atau diturunkan.

Untuk menguji kebenaran dari hipotesis yang diajukan, maka akan diuji dengan regresi linier berganda dengan menggunakan program SPSS sebagaiberikut: (Sugiyono.2010:298) $\mathrm{Y}=\mathrm{a}+\mathrm{b} 1 \mathrm{X} 1+\mathrm{b} 2 \mathrm{X} 2+\mathrm{e}$

\section{Koefisien diterminasi}

Koefisien diterminasi $\left(\mathrm{R}^{2}\right)$ bertujuan untuk melihat pengaruh secara simultan, yang menunjukan derajat hubungan antara $\mathrm{X}$ dan $\mathrm{Y}$

Uji t

Uji t digunakan untuk menguji variabel-variabel bebas yang terdiri dari faktor internal $\left(\mathrm{X}_{1}\right)$ dan faktor eksternal $\left(\mathrm{X}_{2}\right)$ terhadap variabel terkait yaitu kepuasan pengunjung (Y) secara parsial

Uji F

Dalam penelitian ini untuk mengetahui tingkat signifikansi pengaruh variabel-variabel independen variabel dependen dilakukan dengan menggunakan uji $\mathrm{F}$ yaitu dengan cara membandingkan antara $\mathrm{F}_{\text {hitung }}$ dengan $\mathrm{Ft}_{\text {abel }}$. Bila $\mathrm{F}_{\text {hitung }}>\mathrm{F}_{\text {tabel, }}$, maka $\mathrm{H}_{\mathrm{o}}$ ditolak dan $\mathrm{H}_{\mathrm{a}}$ diterima berarti terdapat pengaruh simultan 


\section{HASIL PENELITIAN}

Pembangunan Masjid Agung Nasionl Islamic Centre (MANIC) Pasir Pengaraian, dimulai dengan peletakan batu pertama, di awal tahun hijriah dan di penghujung masehi, tepatnya Senin 1 Muharram 1429 H bersamaan dengan 29 Desember 2008 M, oleh Bupati Rokan Hulu, acara ini di hadiri oleh Kepala Dinas/Badan dan Kantor yang disaksikan oleh Dr. Mustafa Umar, MA, penceramah ahli tafsir Provinsi Riau. Setelah mengalami proses lebih kurang satu setengah tahun, maka pembangunan masjid yang menjadi kebanggaan masyarakat Rokan Hulu telah dapat digunakan, yang di resmikan pada hari, jum'at 25 Sya'ban $1431 \mathrm{H}$ bersamaan dengan 6 Agustus 2010 oleh Bupati Rokan Hulu

\section{Uji Validitas}

Uji validitas digunakan untuk mengukur valid atau tidaknya suatu kuisioner. Pengujian dilakukan dengan membandingkan $r_{\text {hitung }}$ dengan $r_{\text {tabel. }}$.

\section{Uji Validitas}

\begin{tabular}{|l|l|c|}
\hline No & Pertanyaan & $\begin{array}{l}\text { Corrected Item- } \\
\text { Total Correlation }\end{array}$ \\
\hline 1 & $\begin{array}{l}\text { Word of mouth } \\
(\mathrm{X} 1)\end{array}$ & \\
\hline & Item-1 & 0.869 \\
\hline & Item-2 & 0.512 \\
\hline & Item-3 & 0.882 \\
\hline 2 & Citra merek (X2) & 0.645 \\
\hline & Item-1 & 0.698 \\
\hline & Item-2 & 0.678 \\
\hline & Item-3 & 0.717 \\
\hline & Item-4 & \\
\hline 3 & $\begin{array}{l}\text { Keputusan } \\
\text { berkunjung (Y) }\end{array}$ & 0.666 \\
\hline & Item-1 & 0.657 \\
\hline & Item-2 & 0.487 \\
\hline & Item-3 & 0.808 \\
\hline & Item-4 & 0.810 \\
\hline & Item-5 \\
\hline \multicolumn{2}{|l}{ Sumber: Data Olahan SPSS }
\end{tabular}

\section{Uji Reliabilitas}

Uji reliabilitas dapat dilakukan dengan menggunakan bantuan program SPSS, yang akan memberikan fasilitas untuk mengukur reliabilitas dengan uji statistik Cronbach Alpha ( $\alpha)$. Suatu variabel dikatakan reliabel jika memberikan nilai Cronbanch Alpha> 0,60 .

Tabel 4.6 Hasil Uji Reliabilitas

\begin{tabular}{|c|l|c|}
\hline No & $\begin{array}{c}\text { Item } \\
\text { Pertayaan }\end{array}$ & $\begin{array}{c}\text { Cronbach } \\
\text { Alpha }\end{array}$ \\
\hline 1 & $\begin{array}{l}\text { Word of } \\
\text { mouth }\end{array}$ & 0.641 \\
\hline 2 & Citra merek & 0.622 \\
\hline 3 & $\begin{array}{l}\text { Keputusan } \\
\text { berkunjung }\end{array}$ & 0.719 \\
\hline
\end{tabular}

Sumber: Data Olahan SPSS

Dari tabel 4.6 memperlihatkan nilai Cronbach Alpha semua variabel lebih dari 0.60. Kuisioner yang digunakan oleh masing-masing variabel dinyatakan valid untuk dapat dipercaya sebagai alat ukur variabel.

Pengujian Prasyarat

Sebelum data dianalisis, maka terlebih dahulu dilakukan pengujian persyaratan analisis yang meliputi uji normalitas, heteroskedastisitas dan multikolinieritas. Data mentah yang diperoleh dari kuisoner dilakukan proses kuantifikasi untuk mengetahui skor masing-masing variabel.

\section{Uji Normalitas}

Uji normalitas digunakan untuk menguji apakah dalam suatu model regresi, variabel terikat, variabel bebas dan keduanya mempunyai ditribusi normal atau mendekati normal (Ghozali, 2013 : 160). 
Tabel 4.10 Uji Normalitas

One-Sample Kolmogorov-Smirnov Test

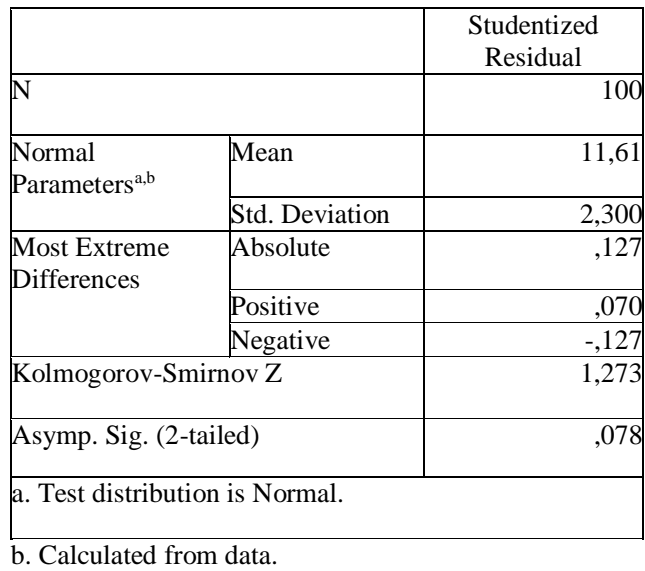

Bedasarkan tabel 4.10 dapat diketahui bahwa nilai signifikan 0,078 lebih besar dari 0,05, sehingga dapat disimpulkan bahwa data yang diuji berdistribusi normal.

\section{Uji Heteroskedastisitas}

Uji heteroskedastisitas digunakan untuk menguji apakah dalam suatu model regresi terjadi ketidaksamaan varian residual dari suatu pengamatan kepengamatan lain. (Ghozali,2013:13).

\section{Tabel 4.11 Uji Heteroskedastisitas}

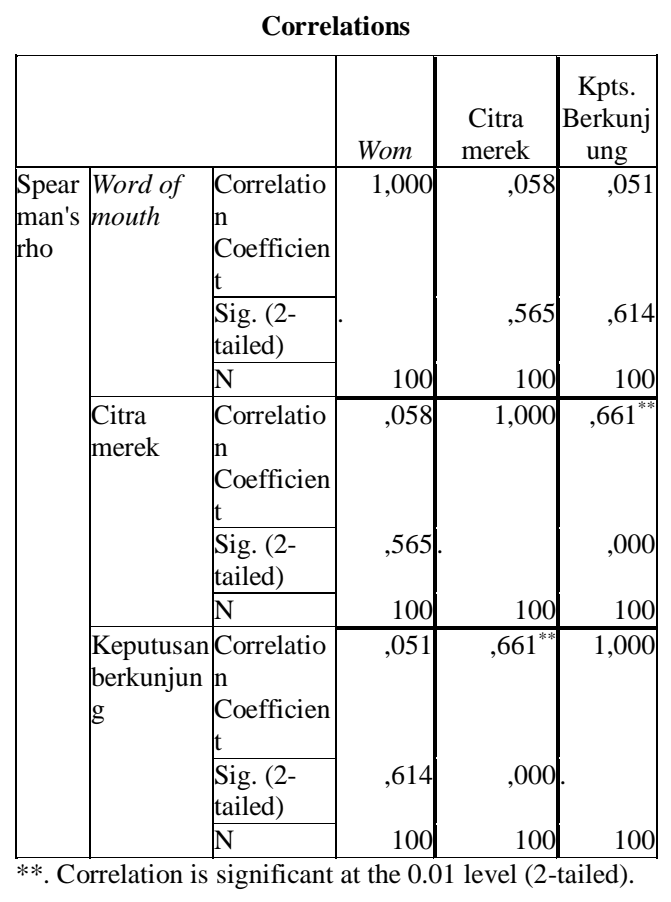

Berdasarkan tabel 4.11 dapat diketahui bahwa nilai korelasi kedua variabel independent dengan unstandardized residual memiliki nilai signifikan lebih dari 0,05. Karena signifikan lebih dari 0,05 maka dapat disimpulkan bahwa tidak terjadi masalah heteroskedastisitas sehingga model regresi layak dipakai untuk memprediksi variabel Y.

\section{Uji Multikolinieritas}

Uji multikolinieritas bertujuan untuk menguji apakah model regresi ditemukan adanya korelasi antar variabel bebas (independent). Untuk mendeteksi adanya multikolinieritas dapat dilihat dari besaran variance inflation faktor (VIF) dan tolerance. Merupakan ketentuan yang mana nilai VIF> 10 dan tolerance $>1$ maka akan terjadi multikolineritas. Hasil pengujian dapat dilihat pada tabel 4.12 berikut ini :

\section{Tabel 4.12 Uji Multikolineritas}

\begin{tabular}{|c|c|c|c|}
\hline \multicolumn{4}{|c|}{ Coefficients $^{\mathrm{a}}$} \\
\hline \multirow{2}{*}{\multicolumn{2}{|c|}{ Model }} & \multicolumn{2}{|c|}{$\begin{array}{c}\text { Collinearity } \\
\text { statistics }\end{array}$} \\
\hline & & Tolerance & VIF \\
\hline 1 & $\mathbf{X}$ & 997 & 1,003 \\
\hline
\end{tabular}

Dari tabel 4.12 dapat dilihat bahwa nilai variance inflation factor (VIF) yaitu word of mouth dan citra merek dengan nilai 1,003, diduga antar variabel independen tidak terjadi persoalan multikolinieritas.

Analisis Regresi Linear Berganda

\section{Tabel 4.13}

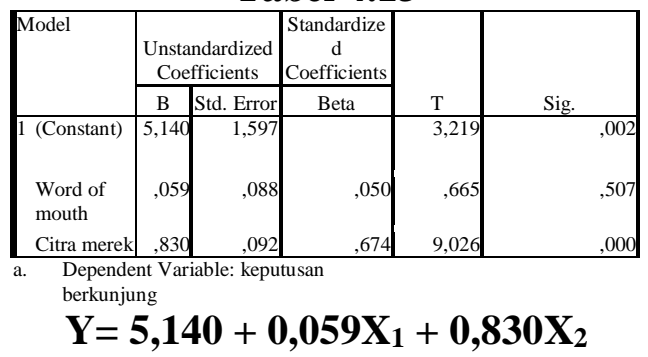


1. Nilai constanta (a) sebesar 5,140 memberikan pengertian bahwa jika word of mouth $\left(\mathrm{X}_{1}\right)$, citra merek $\left(\mathrm{X}_{2}\right)$ secara serempak atau bersama-sama tidak mengalami perubahan atau sama dengan nol (0) maka besarnya keputusan berkunjung (Y) sebesar 5,140 satuan.

2. Nilai constanta (a) sebesar 5,140 memberikan pengertian bahwa jika word of mouth $\left(\mathrm{X}_{1}\right)$, citra merek $\left(\mathrm{X}_{2}\right)$ secara serempak atau bersama-sama tidak mengalami perubahan atau sama dengan nol (0) maka besarnya keputusan berkunjung (Y) sebesar 5,140 satuan.

3. Jika nilai $\mathrm{X}_{1}$ yang merupakan koefisien regresi dari word of mouth $\left(\mathrm{X}_{1}\right)$ sebesar 0,059 yang artinya bahwa variabel word of mouth tidak berpengaruh secara signifikan karena nilainya diatas 0,05 maka hasil penelitian ini menunjukkan bahwa word of mouth tidak mempengaruhi keputusan berkunjung pada wisata religi Masjid Agung Islamic Centre Kabupaten Rokan Hulu.

4. Jika nilai $X_{2}$ yang merupakan koefisien regresi dari citra merek $\left(\mathrm{X}_{2}\right)$ sebesar 0,830 yang artinya mempunyai pengaruh positif terhadap variabel dependen $(\mathrm{Y})$ mempunyai arti bahwa jika variabel citra merek $\left(\mathrm{X}_{2}\right)$ bertambah 1 satuan, maka Keputusan berkunjung (Y) akan mengalami Kenaikan sebesar 0,830 satuan dengan asumsi variabel lain tetap atau konstan.

\section{Koefisien Determinasi $\left(\mathbf{R}^{\mathbf{2}}\right)$}

Koefisien determinasi $\left(\mathrm{R}^{2}\right)$ adalah kemampuan variable $\mathrm{X}$ (variable independent) mempengaruhi variable $\mathrm{Y}$ (variable dipendent). Nilai $\mathrm{R}$ berkisar antara $0-1$, nilai mendekati 1 berarti hubungan yang terjadi semakin kuat, sebaliknya nilai mendekati 0 berarti hubungan yang terjadi semakin lemah.

Tabel. 4.14 Koefisien Determinasi

$\left(\mathbf{R}^{2}\right)$

\begin{tabular}{|l|c|r|r|c|}
\hline Model & $\mathrm{R}$ & $\begin{array}{c}\mathrm{R} \\
\text { Square }\end{array}$ & $\begin{array}{c}\text { Stdjusted R } \\
\text { Square }\end{array}$ & $\begin{array}{c}\text { Error } \\
\text { of the } \\
\text { Estima } \\
\text { te }\end{array}$ \\
\hline 1 & $.679^{\mathrm{a}}$ & .461 & .450 & 2,015 \\
\hline
\end{tabular}

Sumber: Data olahan SPSS 2018

Berdasarkan pada tabel 4.14 nilai koefisien determinansi $\mathrm{R}^{2}$ sebesar 0,461ini artinya word of mouth dan citra merek berpengaruh secara simultan terhadap keputusan berkunjung pada wisata Religi Masjid Agung Islamic Centre Kabupaten Rokan Hulu sebesar $46,1 \%$ dan sisanya sebesar $53,9 \%$ yang tidak diteliti dalam penelitian ini.

\section{Uji T}

Untuk membuktikan pengaruh word of mouth dan citra merek terhadap keputusan berkunjung secara parsial apakah signifikan atau tidak dapat pula dibuktikan dengan uji thitung sebagai berikut :

\section{Coeficients $^{\mathrm{a}}$}

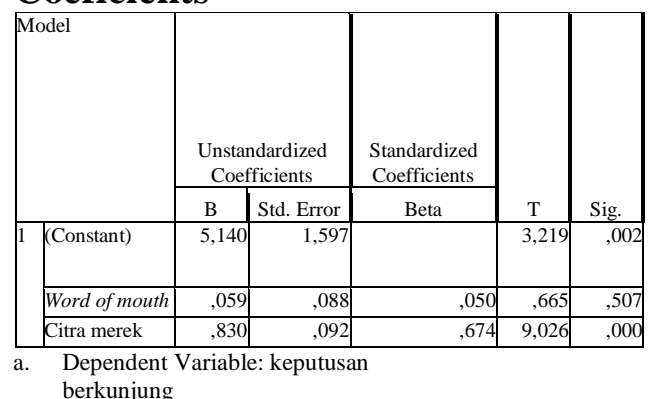


1. Dari hasil Uji $\mathrm{t}$ diperoleh nilai $\mathrm{T}_{\text {hitung }}$ untuk variabel $\left(\mathrm{X}_{1}\right)$ sebesar 0,665 (lebih kecil dari $\left.\mathrm{T}_{\text {tabelsebesar }} 1.660\right)$ dan $\mathrm{P}_{\text {value }}$ sebesar 0,507>0,05, maka hasil penelitian ini menunjukkan bahwa word of mouth tidak mempengaruhi keputusan berkunjung pada wisata religi Masjid Agung Islamic Centre Kabupaten Rokan Hulu.

2. Dari hasil Uji $t$ diperoleh nilai $\mathrm{T}_{\text {hitung }}$ untuk variabel citra merek $\left(\mathrm{X}_{2}\right)$ sebesar 9,026 (lebih besar dari $t_{\text {tabel }}$ sebesar 1.660) dan $\mathrm{P}_{\text {value }}$ sebesar $0,000<0,05$, maka hasil penelitian ini menunjukkan bahwa citra merek mempengaruhi keputusan berkunjung pada wisata religi Masjid Agung Islamic Centre Kabupaten Rokan Hulu.

\section{Uji F}

Selanjutnya, untuk membuktikan pengaruh word of mouth dan citra merek terhadap keputusan berkunjung secara simultan apakah signifikan atau tidak, dapat pula dibuktikan dengan uji $\mathrm{F}$ hitung sebagai berikut :

Tabel 4.15 Uji F Hitung

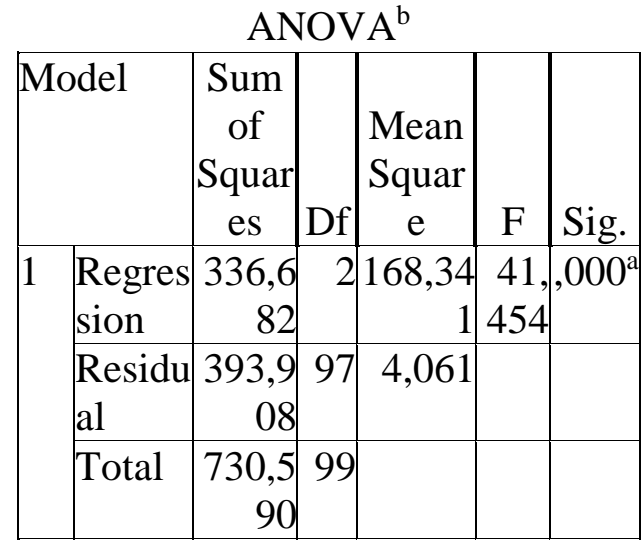

a. Predictors: (Constant), Word of mouth, Citra merek,

b. Dependent Variable: Keputusan berkunjung
Dari hasil Uji $F$ diperoleh nilai $F_{\text {hitung }}$ untuk variabel keputusan berkunjung sebesar 41,454 (lebih besar dari $F_{\text {tabel }}$ sebesar 1.39) dan $\mathrm{P}_{\text {value }}$ sebesar $0,000<0,05$, maka hasil penelitian ini menunjukkan bahwa secara simultan keputusan berkunjung di pengaruhi oleh variabel word of mouth dan citra merek terhadap keputusan berkunjung pada wisata religi Masjid Agung Islamic Centre Kabupaten Rokan Hulu.

\section{PENUTUP}

\section{Kesimpulan}

Berdasarkan hasil penelitian dan pembahasan terhadap hasil penelitian dapat disimpulkan sebagai berikut:

1. Dari hasil Uji t diperoleh nilai $\mathrm{T}_{\text {hitung }}$ untuk variabel word of mouth $\left(\mathrm{X}_{1}\right)$ sebesar 0,665 (lebih kecil dari $\mathrm{T}_{\text {tabel }}$ sebesar 1.660) dan $\mathrm{P}_{\text {value }}$ sebesar $0,000<0,05$ dengan nilai signifikan 0.507 , yang artinya bahwa variabel word of mouth tidak berpengaruh secara signifikan karena nilainya diatas 0,05.Hal ini mengindikasikan bahwa keputusan berkunjung tidakdipengaruhi oleh variabel word of mouth yang meliputi isi pesan tidaksesuai dengan informasi, kejelasan informasi yang diberikan,kurangnya kekuatan dari rekomendasi yang diinformasikan. Nilai jumlah TCR sebesar 77,4\% dengan klasifikasi tingkat capaian responden pada kriteria cukup baik. Dalam penelitian ini perlu adanya peningkatan yang lebih untuk mendapatkan keputusan berkunjung, yaitu meneruskan informasi dari satu pengunjung ke pengunjung yang lain melalui 
mulut ke mulut, yang memiliki niat untuk melakukan keputusan berkunjung kembali.

2. Dari hasil Uji t diperoleh nilai $\mathrm{T}_{\text {hitung }}$ untuk variabel citra merek $\left(\mathrm{X}_{2}\right)$ sebesar 9,026 (lebih besar dari $\mathrm{T}_{\text {tabel }}$ sebesar 1.660) dan $\mathrm{P}_{\text {value }}$ sebesar $0,000<0,05$, berpengaruh positif secara signifikan. Hal ini mengindikasikan bahwa keputusan berkunjung dipengaruhi oleh variabel citra merek yang meliputi Kesan profesional, kesan modren, melayani semua segmen, perhatian kepada konsumen. Nilai jumlah TCR sebesar 69,05\% dengan klasifikasi tingkat capaian responden pada kriteria cukup baik, untuk itu perlu adanya peningkatan atau mempertahankan yang lebih untuk mendapatkan keputusan berkunjung, agar pengunjung wisata religi pada Masjid Agung Islamic Centre memberikan pandangan dan kesan yang baik.

3. Dari hasil Uji f diperoleh nilai $T_{\text {hitung }}$ untuk variabel keputusan berkunjung pada wisata religi Masjid Agung Islamic Centre sebesar 41,454 (lebih besar dari $\mathrm{T}_{\text {tabel }}$ sebesar 1.39) dan $\mathrm{P}_{\text {value }}$ sebesar $0,000<0,05$, maka hasil penelitian ini menunjukkan bahwa secara simultan berpengaruh positif dan secara signifikan keputusan berkunjung di pengaruhi oleh variabel word of mouth dan citra merek yang mana variabel keputusan berkunjung (Y) diperoleh nilai TCR sebesar $69,16 \%$ dengan nilai klasifikasi tingkat capaian responden cukup baik. Keputusan berkunjung pada wisata religi Masjid Agung Islamic Centre Kabupaten Rokan Hulu sebesar $46,1 \%$ dan sisanya sebesar $53,9 \%$ yang tidak diteliti dalam penelitian ini.

\section{Saran}

1. Uji $t$ diperoleh nilai $T_{\text {hitung }}$ untuk variabel word of mouth $\left(\mathrm{X}_{1}\right)$ sebesar 0,665 (lebih kecil dari $\mathrm{T}_{\text {tabel }}$ sebesar 1.660) dan $\mathrm{P}_{\text {value }}$ sebesar $0,000<0,05$ dengan nilai signifikan 0.507, yang artinya bahwa variabel word of mouth tidak berpengaruh secara signifikan karena nilainya diatas 0,05. Hal ini mengindikasikan bahwa keputusan berkunjung tidak dipengaruhi oleh variabel word of mouth. Maka dari itu perlu adanya penyampaian isi pesan sesuai dengan informasi, memberikan kejelasan informasi yang diberikan, meningkatkan kekuatan dari rekomendasi yang diinformasikan.

2. Variabel citra merek berpengaruh signifikan dan positif terhadap keputusan berkunjung di antara variable lainnya sehingga pihak manajemen diharapkan selalu menjaga kepuasan pengunjung dan mempertahankan kepercayaan serta kenyamanan pengunjung yang telah dibangun selama ini diantaranya memperluas informasi yang sesuai dengan kenyataan atau kondisi Masjid Agung Islamic Centre Kabupaten Rokan Hulu.

3. Untuk mempertahankan keputusan berkunjung pada Masjid Agung Islamic Centre Kabupaten Rokan Hulu yang di pengaruhi oleh variabel word of mouth dan citra merek tersebut dapat digunakan sebagai bahan 
pertimbangan untuk lebih meningkatkan jumlah kunjungan wisata sehingga secara terus menerus dapat mempengaruhi keinginan masyarakat untuk berwisata kembali dengan memberikan isi pesan sesuai dengan informasi, kejelasan informasi yang diberikan, melayani semua segmen, serta perhatian kepada pengunjung.

4. Diketahui bahwa penelitian ini hanya terbatas pada word of mouth dan citra merek terhadap keputusan berkunjung sehingga masih banyak faktor-faktor lain yang bisa di teliti oleh peneliti selanjutnya.

\section{DAFTAR PUSTAKA}

Amanah, Dita. 2011. Pengaruh Promosi Dan Brand Image (Citra Produk) Terhadap Loyalitas Pembelian Produk Pepsodent Di Ramayana Plaza Jalan Aksara Medan. Jurnal Keuangan dan Bisnis Volume 3 No. 3, November

Andari, dan Napu. 2016, Pengaruh Word Of Mouth Terhadap Keputusan Pembelian Tiket Maskapai Penerbangan Domestik Di Davina Tour And Travel Gorontalo. Jurnal.Tourism and Hospitality Essentials (THE). Vol.VI No.1. hal. 1013

Kotler Philip, 2010. Manajemen Pemasaran, Analisis Perencanaan Implementasi Dan Pengendalian, Prenhallindo,Jakarta.

Ghozali, Imam. 2012. Analisis Multivariate dengan Program SPSS, Badan
Penerbit Universitas Diponegoro, Semaran.

Jillian C. Sweeney, Geoffrey N. Soutar, Tim Mazzarol, 2012, Word of mouth: measuring the power of individual messages, European Journal of Marketing, Vol. 46 Issue: 1/2, pp.237-257

Sugiyono, 2010. Statistik Penelitian. Alfa Beta Bandung. 